\title{
UPAYA PEMBERDAYAAN KELUARGA TKW DALAM MEWUJUDKAN KESEJAHTERAAN RUMAH TANGGA
}

\author{
Ummu Aemanah \\ Fakultas Ushuluddin Adab dan Dakwah IAIN Syekh Nurjati Cirebon \\ u_aemanah@yahoo.com
}

\begin{abstract}
ABSTRAK
Melihat kondisi sosial desa Kalianyar-Krangkeng yang minat warganya, terutama remaja wanita dan para istri yang mau bekerja di luar Negeri menjadi TKW ini cukup menggugah penulis untuk melakukan pemberdayaan, guna memini malisir dampak negative yang ditimbulkan serta memberikan trobosan baru agar masyarakat Desa Kalianyar-Krangkeng lebih produktif, sehingga masyarakat mampu membuka lapangan pekerjaan sendiri agar tidak lagi harus ke luar Negeri sebagai TKW. Setelah melalukan pendampingan dengan menggunakan metode pendampingan Asset Bassed Community Development (ABCD), menghasilkan diantaranya antusias masyarakat akan pentingnya pendidikan mulai meningkat, kesadaran masyarakat untuk memulai usaha sendiri kini sudah terlihat dengan banyaknya masyarakat yang memulai usaha-usaha kecil, seperti menjual sosis bakar, seblak dan lain sebagainya.
\end{abstract}

Kata Kunci: Upaya Pemberdayaan, TKW, Kesejahteraan Rumah Tangga

\begin{abstract}
Seeing the social condition of the village of Kalianyar-Krangkeng, which interests its citizens, especially young women and wives who want to work abroad to become migrant workers, this is enough to inspire writers to empower, in order to minimize the negative impacts and provide new breakthroughs so that the people of Kalianyar-Krangkeng Village are more productive, so that people are able to open their own jobs, so they no longer have to go abroad as migrant workers. After providing assistance with the Asset Bassed Community Development (ABCD) mentoring method, resulting in community enthusiasm for the importance of education starting to increase, the awareness of the community to start their own business is now visible, with many people starting small businesses, such as selling sosis bakar, seblak, and so on.
\end{abstract}

Keywords: Empowerment Efforts, Female Workers, Household Welfare 


\section{A. PENDAHULUAN}

\section{Latar Belakang}

Masyarakat Desa Kalianyar yang mayoritas pekerjaan penduduknya adalah TKW/TKI dan juga Buruh Pabrik di (Jakarta, Bandung, Bogor dan sekitaranya). Karena kebanyakan dari mereka jika tidak bekerja di luar Negeri, maka merantau ke kota metropolitan atau ke luar jawa, sebagai buruh atau bahkan pedagang asongan, dengan latarbelakang pendidikan yang minim tentunya (SD/SMP/SMA). Kebanyakan anak-anak yang lulus SMP, baik lakilaki maupun perempuan dituntut untuk bekerja, punya penghasilan sendiri. Dan biasanya anak perempuan dituntut untuk kerja di luar Negeri sebagai TKW sedangkan laki-laki merantau di dalam Negeri. Dari sini terlihat jelas, bahwa masyarakat Desa Kalianyar adalah mayoritas memiliki kemandirian atau tanggung jawab yang tinggi, karena lingkungan yang memaksa mereka untuk menjadi pribadi yang mandiri di usia dini.

Status pekerjaan tidaklah penting bagi warga sekitar, yang terpenting adalah punya penghasilan. Persaingan gaya hidup juga sangatlah ketat, dikarenakan banyaknya masyarakat yang berprofesi sebagai TKW. Karena TKW dianggapnya sebagai "kaya instan" tidak jarang dari mereka yang membangun rumah besar dengan gaji yang mereka dapatkan. Jadi tidak heran jika rumah para TKW lebih mewah dari pada rumah para pegawai lokal maupun yang berkiprah dalam dunia pendi dikan. Dengan demikian penduduk tersebut tidak lagi mementingkan pendidikan. Sekolah SD/SMP seolah hanya sebagai menunggu cukup usia saja untuk berangkat ke luar Negri sebagai TKW. Semboyannya adalah "percuma sekolah tinggi jika tidak kaya" dan juga "percuma sekolah tinggi-tinggi, ujung-ujungnya juga jadi ibu rumah tangga". Pemahaman yang seperti inilah yang kiranya harus di robohkan agar masyarakat lebih berkembang. Selain itu, mereka juga lupa akan masa depan, sehingga uang yang mereka dapatkan selama bekerja bertahun-tahun di luar Negeri sebagai TKW ludes dalam sekejap. Dari sini terlihat bahwa masyarakat belum bisa mengolah penghasilan yang mereka dapatkan.

Selain para TKW, disana juga banyak tokoh agama yang mempu nyai yayasan, namun seolah-olah yayasan sudah beralih fungsi, bukan lagi sebagai taman pendidikan, mela inkan sebagai ajang bisnis. Banyak juga santri yang berkompeten, santri yang tahfidz dan tidak jarang yang berprestasi. Namun lagi-lagi karena faktor ekonomi dan juga seolah sudah didoktrin oleh lingkungan sehingga banyak sekatsekat yang terlihat mem posisikan peran seseorang.

Anak yang lulus SD biasanya melan jutkan ke dua tempat. Yaitu melanjutkan ke pondok pesantren dan ada juga yang melanjutkan ke SMP/ MTS di Desa tersebut. Biasanya mereka yang mondok selama kurang lebih 6 tahun, kemudian pulang ke rumah, menikah dan menjadi ibu rumah tangga, bahkan ada juga yang menja di TKW. Sedangkan mereka yang tidak mondok, lulus SMP, bekerja sebagai TKW. Padahal jika melihat lingkungan sekitar, banyak potensi-potensi yang terabaikan, yang itu sebenarnya sangat menjanjikan bagi kehidupan masyarakat sekitar. Banyak musholah- 
musholah di Daerah tersebut, namun musholah hanya dipakai sekedarnya saja, hanya untuk jama'ah sholat dan juga marhabanan pada setiap malam jumatnya. Dan itupun hanya segelintir orang yang hadir, lebih mirisnya lagi jarang kaum pemuda yang di musholah bahkan tidak ada. Karena mereka sibuk bekerja dan ketika pulangpun pergaulan sudah berubah. Judi, minum-minuman keras, hamil diluar nikah, sudah biasa.

Dari pemaparan diatas, terlihat jelas bahwa sebenarnya banyak potensipotensi yang ada dalam masyarakat desa Kalianyar ini, namun kurang di perhatikan, sehingga potensi-potensi tersebut tidak terlihat dan terkubur begitu saja. Untuk itu penulis memilih masyarakat desa Kalianyar sebagai subyek dampingan karena dirasa sangat perlu dan sangat butuh pendampingan untuk mewujudkan masyarakat yang lebih cerdas, dan berdaya.

\section{Langkah-Langkah Pendampingan}

Untuk menggali potensi-potensi masyarakat, penulis menggunakan metode pendampingan Asset Bassed Community Development (ABCD), yaitu pendekatan pendampingan yang mengupayakan pengembangan masyarakat harus dilaksanakan sejak dari awal menempatkan manusia untuk mengetahui apa yang menjadi kekuatan yang dimiliki, serta segenap potensi dan aset yang dipunyai yang potensial untuk dimanfaatkan. Pendekatan ABCD merupakan pendekatan yang mengarah pada pemahaman dan internalisasi asset, potensi, kekuatan, dan pendaya gunaannya secara mandiri dan

${ }^{1}$ Tim Penyusun KKN ABCD UIN Sunan Ampel Surabaya, Panduan KKN ABCD UIN Sunan Ampel Surabaya, (Surabaya: LPPM UIN Sunan Ampel, 2015), hlm 26 maksimal. ${ }^{1}$ Dalam metode ABCD ini memiliki lima langkah kunci untuk melakukan proses riset pendampingan, yang dilakukan bersama masyarakat untuk terwujudnya pendampingan yang akan dilakukan bersama. Langkahlangkah tersebut diantaranya: ${ }^{2}$

\section{a. Discovery (Menemukan)}

Proses menemukan kembali kesuksesan dilakukan melalui proses percakapan atau wawancara dan harus menjadi penemuan personal tentang apa yang menjadi kontribusi individu yang memberi hidup pada sebuah kegiatan atau usaha. Pada tahap discovery ini, kami mulai memindahkan tanggung jawab untuk perubahan kepada para individu yang berkepentingan dengan perubahan tersebut yaitu entitas lokal. Pendamping melakukan wawancara kepada masyarakat Kalianyar tentang kondisi kampung. Wawancara tersebut dapat digiring untuk mengetahui potensi yang ada. Wawancara ini bersifat cerita antara masyarakat dengan pendamping sehingga yang banyak berbicara nantinya adalah masyarakat Kalianyar.

\section{b. Dream (Mimpi)}

Dengan cara kreatif dan secara kolektif melihat masa depan yang mungkin terwujud, apa yang sangat dihargai dikaitkan dengan apa yang paling diinginkan. Pada tahap ini, setiap orang mengeksplorasi harapan dan impian mereka baik untuk diri mereka sendiri maupun untuk kelompok. Sebuah mimpi atau visi

${ }^{2}$ Dani Wahyu Munggoro dan Budhita Kasmadi, (eds), Panduan Fasilitator,(Indonesia Australia Partnership: IDSS Acces Phase II, 2008), hlm. 21 
bersama terhadap masa depan yang bisa terdiri dari gambar, tindakan, maupun kata-kata. Setelah melakukan wawancara kepada masyarakat Desa Kalianyar, maka pendamping mulai mengetahui impian atau keinginan masyarakat.

\section{c. Design (Merancang)}

Setelah mengetahui keinginan atau impian masyarakat, maka langkah selanjutnya yaitu merancang sebuah kegiatan untuk memenuhi impian masyarakat. Proses dimana seluruh komunitas terlibat dalam proses belajar tentang kekuatan atau aset yang dimiliki agar bisa mulai memanfaatkannya dalam cara yang konstruktif, inklusif, dan kolaboratif untuk mencapai aspirasi dan tujuan seperti yang sudah ditetapkan sendiri. Proses merencanakan ini merupakan proses cara mengetahui aset-aset yang ada pada masyarakat Desa Kalianyar. Aset yang terlihat di Desa Kalianyar-Krangkeng adalah TKW dan pemuda yang berkompeten. Aset ini yang akan dimanfaatkan untuk memenuhi impian masyarakat Desa KalianyarKrangkeng- Indra mayu.

\section{d. Define (Menetukan)}

Tahap berikutnya yakni define, yaitu masyarakat diminta untuk kembali ke visi masa depan, elemenelemen mana yang mereka rasa paling penting bagi mereka dan menyeru untuk bertindak. Secara bersama-sama, komunitas diminta untuk mengidentifikasi elemenelemen keberhasilan yang

\footnotetext{
${ }^{3}$ Dani Wahyu Munggoro dan Budhita Kasmadi, Panduan Fasilitator, hlm. 26

${ }^{4}$ Dani Wahyu Munggoro dan Budhita Kasmadi, Panduan Fasilitator, hlm. 27
}

diperlukan demi mewujudkan mimpi-mimpi dalam bentuk prinsip, kriteria dan indikator-indikator. ${ }^{3}$

\section{e. Destiny (Memastikan).}

\begin{tabular}{lcr}
\multicolumn{1}{c}{ Tahap } & ini & merupakan \\
serangkaian & tindakan & baru dan \\
inovatif yang & mendukung \\
pembelajaran & dan & inovasi \\
berkelanjutan. Tahap & ini secara
\end{tabular} khusus memusatkan pada komitmen dan arah ke depan individu dan komunitas. $^{4}$ Pada tahapan ini komunitas mulai merumuskan langkah bersama yang bercermin pada papan visi dengan memanfaatkan metode hierarchy of effects atau seringkali disebut Tangga Perubahan. ${ }^{5}$ Serangkaian tindakan inspiratif yang mendukung proses belajar terus menerus dan inovasi tentang "apa yang akan terjadi." Hal ini merupakan fase akhir yang secara khusus fokus pada cara-cara personal dan kelompok untuk melangkah maju. Langkah yang terakhir adalah melaksanakan kegiatan yang sudah disepakati untuk memenuhi impian masyarakat dari pemanfaatan aset yang ada di Desa Kalianyar-Krangkeng tersebut. Selain untuk memenuhi impian masyarakat, Desa tersebut juga bisa lebih berkembang.

Langkah-langkah ini memusatkan posisinya pada kekuatan dan keberhasilan diri dan komunitas yang bertujuan merangsang kreativitas, inspirasi, dan inovasi masyarakat untuk mendapatkan kembali masa kejayaan yang pernah mereka peroleh dahulu.

${ }^{5}$ Dani Wahyu Munggoro dan Budhita Kasmadi, Panduan Fasilitator, hlm. 31 
Kemampuan terkait potensi, kekuatan, keberhasilan, serta dibarengi dengan asset yang mereka miliki akan memberikan energy positif untuk membantu dan mengembalikan kekuatan dan keberhasilan mereka dalam mengubah cara pandang terhadap segala sesuatu menjadi lebih baik dalam segi berbagai hal bahwa kita mampu dan bisa merubah kondisi hidup diri sendiri maupun orang lain.

\section{Kondisi Dampingan Yang Diharap kan}

Perubahan yang diharapkan oleh penulis terhadap masyarakat Desa Kalianyar setelah melakukan pendampingan atau pemberdaya-an diantanya sebagai berikut:

a. Pola pikir masyarakat Desa Kalianyar lebih maju dan berkembang, sehingga tidak lagi me-mandang rendah akan pendidikan, dan pro terhadap perubahan jaman yang positif.

b. Kaya akan pengetahuan, baik penge tahuan lingkungan dan juga spiritual. Sehingga berkuranglah kenakalan remaja yang ada di Desa Kalianyar.

c. Bisa menjadi masyarakat yang lebih produktif, sehingga pekerjaan sebagai TKW yang diandalkan oleh masyarakat Desa Kalianyar yang selama ini sebagai pekerjaan paten, bukan lagi menjadi pekerjaan pokok masyarakat Desa Kalianyar, melainkan sebagai pencarian modal saja untuk memulai usaha baru di kampung sendiri.

d. Meningkatkan kembali peran orang tua di setiap kepala keluarga, sehingga anak-anak di Desa KalianyarKrangkeng-Indramayu lebih terdidik dan tumbuh menjadi anak-anak bangsa yang cerdas. e. Masyarakat Desa KalianyarKrangkeng-Indramayu, tidak lagi dikenal sebagai masyarakat yang tertinggal dan dipandang negative oleh penduduk sekitar, melainkan tumbuh dan berkembang menjadi masyarakat yang ramah, lebih kreatif dan inovatif.

f. Pemuda di Desa KalianyarKrangkeng-Indramayu diharapkan lebih berdaya, tidak lagi terjerumus dalam dunia hitam, sehingga tidak ada lagi perjudian, mabuk-mabukan, dan hamil diluar nikah.

g. Menumbuhkan keluarga yang sakinah, mawaddah wa rahmah di Desa Kalianyar, Krangkeng, Indramayu, sehingga meminimalisir angka perceraian yang ada di Desa tersebut. Karena diharapkan setiap kepala keluarga di Desa tersebut tumbuh menjadi keluarga yang harmonis.

\section{B. KAJIAN TEORI}

\section{Peran Gender}

Gender adalah suatu konsep kultural yang merujuk pada karakteristik yang membedakan antara wanita dan pria baik secara biologis, perilaku, mentalitas, dan sosial budaya. Pria dan wanita secara sexual memang berbeda. Begitu pula secara perilaku dan mentalitas. Namun perannya di masyarakat dapat disejajarkan dengan batasan-batasan tertentu. Gender adalah sebuah bentuk perbedaan peran antara laki-laki dan perempuan yang lebih bersifat perilaku (behavioral differences) yang di konstruksi secara sosial kultural dan berlangsung dalam 
sebuah proses yang panjang. ${ }^{6}$ Jadi, gender merupakan bentukan sosial, maka penempatannya selalu berubah dari waktu kewaktu dan tidak bersifat universal, artinya antara masyarakat yang satu dengan yang lain mempunyai pengertian yang berbeda-beda dalam memahami gender.

Gender berbeda dengan istilah seks. Seks merujuk pada perbedaan jenis kelamin yang secara biologis melekat pada diri perempuan dan lakilaki. ${ }^{7}$ Konstruksi sosial yang dibentuk masyarakat terhadap perempuan adalah laki-laki dianggap memiliki kekuatan lebih dibandingkan perempuan. Masyarakat memandang perempuan sebagai seorang yang lemah dan tidak berdaya khususnya dalam budaya patriarkhi.

\section{Pergeseran Gender}

Mengkaji pola relasi gender dalam institusi keluarga, tidak terlepas dari pengaruh kondisi sosial budaya masyarakat dimana keluarga tersebut bertempat tinggal. Hal tersebut seiring dengan konsep gender itu sendiri, yaitu sebagai suatu kontruksi sosial budaya yang tentunya akan mengikuti kondisi sosial budaya dimana masyarakat tersebut ada. ${ }^{8}$ Pola relasi gender masyarakat yang menganut sistem patriarkhi tentunya akan berbeda dengan masyarakat yang menganut sistem matriarkhi. ${ }^{9}$

Hubungan gender yang terjadi dalam keluarga TKW selama ini masih didominasi oleh sistem patriarkhi. Dominasi suami sebagai pihak yang memegang kekuasaan dalam berbagai aspek. Fenomena TKW yang terjadi pada awal tahun 80an sedikit banyak telah merubah pola hubungan yang patriarkhi selama ini. Nilai patriarkhi yang sarat dengan nilai nilai pemingitan dalam konteks TKW ini ternyata telah mengalami perubahan. Suami sudah lebih bersifat primitive. Independen TKW dalam menentukan keberangkatan cukup tinggi walaupun hal ini juga sangat didukung oleh motivasi ekonomi.

Berbicara pada tataran relasi gender konvensional maka ada perubahan yang signifikan pada lakilaki sebagai kepala rumah tangga. Hal ini tidak diikuti perubahan pada sektor lainnya secara umum. Pengambilan keputusan juga memperlihatkan adanya hubungan patriarkhi yang konvensioanal dengan kadar yang sangat rendah. Pengambilan kepu tusan dalam bidang domestik menjadi wilayah istri, tetapi istri juga sudah masuk pada pengambilan keputusan diwilayah publik, walaupun pada hal tertentu domestik publik kelihatan ditangan suami. ${ }^{10}$

\section{Pembagian kerja}

Dalam kaitanya dengan beban ganda tersebut, prempuan tidak saja berperan ganda, akan tetapi perempuan memiliki triple role (triple burden) $:{ }^{11}$

${ }^{9}$ Harmona Daulay, Pergeseran Pola Relasi Gender di Kelaurga Migran, (Yogyakarta : Galang Press, 2001), hlm. 110

${ }^{10}$ Harmona Daulay, Pergeseran Pola Relasi Gender di Kelaurga Migran, hlm. 115

${ }^{11}$ Dwi Narwoko, dan bagong Sunyoto, (eds), Sosiologi Teks dan Pengantar Terapan, (Jakarta: Kencana 2006), hlm. 345 
a. peran reproduksi, yaitu peran yang berhubungan dengan peran tradisional di sektor domestik

b. peran produktif yaitu peran ekonomis disektor publik

c. peran sosial, yaitu peran dikomunitas.

Apabila orang membahas pekerjaan yang dilakukan perempuan, maka yang dibayangkan mungkin hanya jenis pekerjaan yang dijumpai di ranah publik, pekerjaan ditempat kerja formal seperti pabrik dan kantor, pekerjaan dalam perekonomian formal. Orang sering melakukan kegiatan yang menghasilkan, ada yang menawarkan berbagai jenis jasa, ada yang melakukan perdagagan eceran dan juga ada yang memproduksi atau memproses hasil pertanian, kehutanan, perkebunan, pertanian, perternakan maupun produksi lain untuk dipasarkan. Disamping itu sering dilupakan pula bahwa pekerjaan rumah tangga yang dilakukan perempuan diranah domestik, yaitu penyediaan barang dan jasa bagi sesama anggota keluarga termasuk suami, merupakan suatu pekerjaan produktif. Jenis pekerjaan ini menyita banyak waktu dan tenaga, menguntungkan suami, keluarga, masyarakat, namun tidak diberi imbalan materi dan umumnya dianggap sebagai pekerjaan yang rendah.

\section{Peran Suami dan Istri Dalam Keluarga}

Goode menyatakan bahwa "adanya hubungan kedudukan antara kelas dan kesuksesan sang laki-laki“. ${ }^{12}$ Disini terlihat adanya suatu pertentangan

${ }^{12}$ Wiilam J. Goode, Sosiologi keluarga, (Jakarta: Bumi aksara, 2004), hlm. 151 kearah kesetaraan yang lebih rendah. Suami lebih banyak kemungkinan menuntut kekuasaan nya hanya karena ia seorang laki-laki, tetapi harus memberikan lebih banyak kekuasaan kepada istrinya. Namun dalam kenyataannya bagai manapun juga suami masih lebih banyak mempunyai kekuasaan.

Sedangkan peran menurut
Suratman adalah fungsi atau
tingkahlaku yang diharapkan ada pada individu seksual sebagai status aktivitas yang mencakup peran domestik maupun publik atau dengan kata lain peran perempuan merupakan kegiatan atau aktivitas yang dikerjakan dan dianggap menjadi tanggung jawab perempuan. $^{13}$ Peran perempuan menurut tujuannya dapat dibedakan menjadi tiga bagian :

a. Peran publik, yaitu segala aktivitas manusia yang biasanya dilakukan diluar rumah dan bertujuan untuk mendatangkan penghasilan

b. Peran domestik, yaitu aktivitas yang dilakukan didalam rumah dan biasanya tidak dimaksudkan untuk mendatangkan penghasilan, melainkan untuk melakukan kegiatan kerumahtanggaan. Peran yang dilakukan para perempuan atau Ibu rumah tangga karena ingin kondisi kesejahteraan yaitu sandang, pangan, papan, pendidikan, kesehatan, persiapan materi berbagai jaminan masa depan kehidupannya, ketentraman dan keamanan.

c. Peran Sosial. Peran ini merupakan kebutuhan wanita untuk

${ }^{13}$ M Dahlan Al-Barry dan A Partanto Pius, (eds), Kamus Ilmiah Populer, (Surabaya: Bungin, 2011) 
mengaktualisasikan dirinya dalam masya rakat. Tingkat peranan berbeda-beda sesuai dengan budaya atau kondisi alam dan dengan mengetahui kemampuan nya.

Kompleksitas penting lainya terjadi dalam keadaan dimana laki-laki dan wanita sama-sama mempunyai kekuasaan perbedaan-perbedaan dalam jenis-jenis kekuasaan mungkin juga penting. Kekuasaan laki-laki itu sudah dianggap wajar, ibu pemimpin rumah tangga yang setengah baya atau tua dapat ditemukan dibanyak rumah. Wanita itu menjadi pusat inisiatif dan keputusan. Tetapi laki-laki kepada keluarganya rupanya mengakui kekuasaan itu, dengan tetap berhak mengambilnya kembali jika ia meng hendakinya. ${ }^{14}$

\section{KONDISI AWAL}

\section{Letak Geografi}

Desa kalianyar terletak di Kecamatan Krangkeng Kabupaten Indramayu. Batas wilayah Desa kalianyar adalah sebagai berikut: sebelah utara berbatasan dengan Desa Krangkeng, sebelah selatan berba tasan dengan Desa Luwunggesik, sebelah barat berbatasan dengan Desa Srengseng dan sebelah timur berbatasan dengan Laut Jawa. Sedangkan jumlah Dusun yang ada di Desa kalianyar adalah 4 Dusun. Desa ini memiliki luas wilayah $1.043 \mathrm{Ha}$, luas pemukiman 52 Ha dan luas perkan toran 0,7 Ha. Desa kalianyar berada di ketinggian $3 \mathrm{mdl}$, diatas permukaan laut, dengan curah hujan $2000 \mathrm{Mm}$, dan suhu rata-rata 151

${ }^{14}$ Wiilam J. Goode, Sosiologi keluarga, hlm.

${ }^{15}$ Format Laporan Perkembangan Desa Dan Kelurahan (Desa Kalianyar, Kec.Krangkeng, Kab. Indramayu), 2015. $28^{\circ} \mathrm{C} .{ }^{15}$ Dari pemaparan diatas Desa ini tergolong pada wilayah yang bersahabat dengan matahari. Selain itu desa Kalianyar juga memiliki luas tanah yang tidak ada erosinya yang cukup luas, sehingga masyarakat setempat mayoritas bermata pencaharian tani dan nelayan.

\section{Monografi}

Desa kalianyar merupakan salah satu Desa yang terletak di Kecamatan Krangkeng Kabupaten Indramayu dengan jumlah penduduk 6.944 jiwa yang terdiri dari 3.469 jiwa berjenis kelamin laki-laki dan 3.475 jiwa berjenis kelamin perempuan. Berdasarkan data yang telah diperoleh, sacara garis besar masyarakat Desa Kalianyar merupakan masyarakat yang memiliki tingkat perekonomian menengah kebawah. Hal ini terlihat dari ragam profesi yang digeluti oleh masyarakat desa tersebut, dimana sebagian besar dari keseluruhan jumlah penduduk masih tergantung pada kegiatan-kegiatan agraris sebagai petani dan juga TKW. ${ }^{16}$

\section{Lokus Pemberdayaan}

Penelitian ini dilakukan di Desa kalianyar Kecamatan Krangkeng, Kab. Indramayu. Pertimbangan pemilihan lokasi tersebut berdasarkan tinjauan deskriptif, dimana masih dirasakan perlu adanya pendampingan, karena masyarakat Desa ini sebenarnya memiliki potensi-potensi untuk berkembang, dan memiliki aset yang memadai untuk menjadi masyarakat yang produktif, diantanya adalah dari

${ }^{16}$ Format Laporan Perkembangan Desa Dan Kelurahan (Desa Kalianyar, Kec.Krangkeng, Kab. Indramayu), 2015. 
SDM masyarakat tersebut, Banyak santri yang berkompeten, santri yang hafidz dan tidak jarang yang berprestasi. Namun lagi-lagi karena faktor ekonomi dan juga seolah sudah didoktrin oleh lingkungan sehingga banyak sekat-sekat yang terlihat memposisikan peran seseorang. Selain itu banyak juga tokoh masyarakat maupun tokoh agama, namun belum menyatu dengan masyarakat sekitar. dan juga di daerah ini masih banyak masyarakat yang bertahun-tahun bekerja menjadi TKW, namun mereka masih belum mampu mengatur penghasilan mereka, sehingga upah/gaji yang mereka dapatkan selama bertahuntahun, tidak ada hasilnya.

Diantara potensi-potensi tersebut dapat dilihat pada tabel tingkat pendidikan masyarakat menurut data yang telah diperoleh oleh penulis. di Desa Kalianyar jumlah penduduk menurut tingkat pendidikan sebagai berikut: ${ }^{17}$

\section{Jumlah Penduduk Menurut Tingkat Pendidikan}

\begin{tabular}{|c|c|c|c|}
\hline No & Tingkat Pendidikan & Laki-Laki & Perempuan \\
\hline 1 & Usia 3-6 tahun yang belum masuk TK & 61 Orang & 55 Orang \\
\hline 2 & Usia 3-6 tahun yang sedang TK/play group & 33 Orang & 38 Orang \\
\hline 3 & Usia 7-18 tahun yang tidak pernah sekolah & 2 Orang & 4 Orang \\
\hline 4 & Usia 7-18 tahun yang sedang sekolah & 739 Orang & 710 Orang \\
\hline 5 & Usia 18-56 tahun yang tidak pernah sekolah & 77 Orang & 56 Orang \\
\hline 6 & Usia 18-56 tahun yang pernah SD tapi tidak tamat & 243 Orang & 258 Orang \\
\hline 7 & Tamat SD/sederajat & 941 Orang & 885 Orang \\
\hline 8 & Tamat SMP/sederajat & 457 Orang & 435 Orang \\
\hline 9 & Tamat SMA/sederajat & 248 Orang & 194 Orang \\
\hline 10 & Tamat D1/sederajat & 17 Orang & 16 Orang \\
\hline 11 & Tamat D2/sederajat & 13 Orang & 11 Orang \\
\hline 12 & Tamat D3/sederajat & 4 Orang & 7 Orang \\
\hline 13 & Tamat S1/sederajat & 23 Orang & 19 Orang \\
\hline 14 & Tamat S2/sederajat & 2 Orang & - \\
\hline 15 & Usia 0-3 tahun & 173 Orang & 236 Orang \\
\hline \multicolumn{2}{|r|}{ Jumlah Total } & 3,003 Orang & 2.924 Orang \\
\hline
\end{tabular}

Sedangkan untuk tingkat pendidikan non formalnya, kebanyakan dilalui di Pondok-pondok Pesantren baik yang ada di Desa Kalianyar sendiri maupun yang ada di luar Desa tersebut. Ada juga pendidikan non formal lain yang ada di Desa Kalianyar, diantaranya adalah TKA/ TPA/TQA, MD,MI, MTs, MA.
D. PROSES PENDAMPINGAN

\section{Pelaksanaan Kegiatan Pendam pingan}

Pelaksanaan pendampingan pada masyarakat TKW di desa Kalianyar kecamatan krangkeng kabupaten indramayu, guna untuk menjadi

${ }^{17}$ Format Laporan Perkembangan Desa Dan Kelurahan (Desa Kalianyar, Kec.Krangkeng, Kab. Indramayu), 2015. 
masyarakat yang produktif adalah sebagai berikut:

a. Melakukan pertemuan dengan kepala desa Kalianyar, guna menyampaikan ide-ide atau kegiatan-kegiatan yang bersifat membangun, sekaligus melakukan lobying, sehingga kepala Desapun menyetujui serta mendukung kegiatan yang telah direncanakan.

b. Kepala desa mengumpulkan stake holder yang ada di Desa Kali anyarKrangkeng, guna memusyawarakan perencanaan tersebut, serta merumuskan kegiatan-kegiatan yang mendukung dalam pendampingan masyarakat khususnya warga TKW.

c. Melakukan diskusi atau musyawarah dengan mahasiswa-mahasiswa setempat, guna merumuskan, dan merancang kegiatan yang signifikan dalam upaya pemberdayaan masyarakat Desa Kalianyar, khususnya keluarga TKW.

d. Sosialisasi atau pembekalan pada TKW yang masih ada di tanah air, tepatnya di penampungan Desa, tentang tujuan bekerja sebagai TKW bukan untuk pekerjaan yang paten atau selamanya, melainkan untuk mencari modal usaha, sehingga kerja keras mereka sebagai TKW terbayarkan, ketika mereka kembali ke tanah kelahiran.

e. Sosialisasi atau pembekalan terhadap keluarga TKW yang berada di rumah, agar tidak mengandalkan kiriman atau penghasilan dari mereka yang bekerja di luar Negeri, melainkan keluarga yang di rumahpun harus mempunyai penghasilan, meski hanya cukup untuk makan sehari-hari. f. Mengaktifkan kembali kegiatan PKK yang selama ini masih pasif, atau belum terlalu kelihatan di masyarakat, dengan mengadakan pelatihan-pelatihan yang bersifat produktif, sehingga hasil dari pelatihan tersebut bisa di distri busikan, seperti pelatihan toples hias, yang nantinya bisa di jual pada saat bulan ramadhan.

g. Mengaktifkan kembali pembinaan terhadap keluarga TKW yang selama ini masih kurang efektif. Yang dilakukan oleh kepala Desa dan ketua pembinaan TKW di Desa Kalianyar.

\section{Kendala Yang Dihadapi}

Dalam proses pendampingan masyarakat TKW di Desa KalianyarKrangkeng ini, tentu saja ada banyak kendala yang dihadapi. Diantara kendala-kendala tersebut adalah sebagai berikut:

a. Masih kurangnya kesadaran masyarakat akan hidup bersama, dalam artian masih mementingkan kepuasana individu.

b. Masih banyakya masyarakat yang enggan bekerja di dalam Negeri, atau membuka usaha sendiri dikarenakan tergiur dengan nominal gaji yang di dapatkan dari hasil bekerja sebagai TKW, dalam artian masih banyak masyarakat yang membandingbandingkan penghasilan bekerja di luar Negeri dan dalam Negeri.

c. Banyaknya pemuda yang sudah kecanduan dengan minum-minuman dan narkoba, sehingga susah bagi kami untuk mengajak mereka dalam proses pendampingan, di karenakan pribadi mereka yang masih mengkotak-kotakkan antara mereka yang nakal dan yang tidak. 
d. Kurangnya anggaran dana Desa untuk kegiatan pendampingan, dikarenakan masih ada oknum yang menyalah gunakan anggaran dana untuk kepentingan pribadi.

e. kurangnya tingkat kesadaran subjek dalam melakukan peru bahan yang dimulai dari diri mereka masingmasing. Ada juga yang ingin ikut merubah diri mereka namun terhalang oleh beberapa pekerjaan yang biasa mereka tekuni sebagai mata pencaharian mereka.

\section{Strategi Pemecahan Masalah}

Tahap memberdayakan masyarakat TKW di Desa Kalianyar, tentunya tidak sertamerta tercapai begitu saja, melaikan diperlukan berbagai strategi untuk menjamin perwujudan pemberdayaan tersebut. Dengan melihat asset yang ada di masyarakat Kalianyar, penulis mencoba bertahap untuk mewujudkan perubahan positif pada masyarakat desa KalianyarKrangkeng tersebut. Dalam upaya perwujudan pemberdayaan ini, penulis menggunakan beberapa strategi, diantaranya yaitu:

a. Memberikan sosialisasi serta mendorong masyarakat menggunakan cara positif untuk melakukan perubahan pada masyarakat Desa Kalianyar berda sarkan asumsi yang sederhana yaitu bahwa setiap masyarakat memiliki sesuatu yang dapat bekerja dengan baik, sesuatu yang menjadikan masyarakat itu hidup, efektif dan berhasil, serta menghubungkan masyarakat tersebut dengan komunitas dan stakeholdernya dengan cara yang sehat.

b. Dalam usaha memberdayakan masyarakat Kalianyar, dimulai dengan mengidentifikasi hal-hal positif dan menghubungkannya dengan cara yang dapat memperkuat energi dan visi untuk melakukan perubahan dalam hal ini mewujudkan masa depan masyarakat Desa Kalianyar yang lebih baik, terutama keluarga TKW.

c. Melihat isu dan tantangan masyarakat dengan cara yang berbeda. Berdeda dengan pendekatan yang fokus pada masalah, dalam hal ini, kami lebih men dorong anggota masyarakat untuk fokus pada hal-hal positif, yang terdapat dan bekerja dengan baik dalam masyarakat tersebut. Seperti mengaktifkan kembali komunitas atau organisasi-organisasi masyarakat, diantaranya PKK, Karangtaruna dan lain sebagainya dan juga kegiatan-kegiatan positif lainnya yang selama ini dianggap kurang berjalan maksimal.

d. Dalam strategi memberdayakan masyarakat TKW di Desa Kalianyar ini, penulis tidak menganalisis akar masalah dan solusi, tetapi lebih konsen pada bagaimana memperbanyak hal-hal positif dalam masyarakat. Karena dalam hal ini penulis mencoba untuk menerapkan poin-poin yang terdapat dalam metode pendam pingan (ABCD). Dalam hal strategi pemecahan masalah ini, penulis menggunakan Model atau Siklus 4-D, yang diwujudkan dengan mengevaluasi kembali organisasi-organisasi masyarakat, dengan mengadakan kegiatan-kegiatan yang positif bagi masyarakat. 
E. PERUBAHAN DAN HASIL PEMBER DAYAAN

Dalam kehidupan sosial, setiap masyarakat mempunyai peran masingmasing yang harus dijalankan. Salah satu lembaga sosial dasar yaitu keluarga. Dalam keluarga, terdapat sepasang suami istri yang tentunya mempunyai peran masing masing, peran keluarga menggambarkan seperangkat perilaku interpersonal yang berhubungan dengan posisi dan situasi tertentu yang harus dijalankan, agar kehidupan keluarga tersebut tidak berantakan, karena di dalam peran tersebut telah terbagi dengan sendirinya yang berupa tugas masing masing antara suami dan istri.

Perempuan dengan status dan peran yang mengharuskan mereka untuk bergelut disektor domestik, yaitu bagi perempuan yang telah menikah harus menjalani peran sebagai istri, sebagai ibu dan sebagai pengurus rumah tangga. Namun sekarang ini banyak perempuan yang telah memasuki sektor publik, sebagai anggota kelompok sosial dan anggota masyarakat, serta berperan sebagai pencari nafkah tambahan bagi keluarga. Berperannya perempuan pada sektor publik, ternyata berdampak pada penghasilan tetap yang dapat digunakan untuk kebutuhan rumah tangga, dan biaya pendidikan anak. Karena suami tidak memiliki pekerjaan tetap, maka posisi istri berganti menjadi pencari nafkah utama dalam keluarga sedangkan suami lebih banyak waktu dirumah.

Ketika seorang istri memutuskan untuk bekerja menjadi TKW dengan tujuan untuk membantu perekonomian keluarga, segala hal yang berkaitan dengan peran-peran istri di sektor domestik tersebut terjadi pergeseran, yang mana istri tidak memegang lagi segala peran yang menjadi tanggung jawabnya, melainkan istri telah melakukan peran yang semestinya dilakukan oleh suami yaitu mencari nafkah untuk memenuhi kebutuhan keluarga. Dan dampak dari pergeseran relasi gender di antaranya adalah anak yang kurang terurus, kurang mendapatkan kasih sayang dari seorang ibu hingga menyebabkan kenakalan pada anak. Kasih sayang seorang istri juga kurang didapatkan oleh suami, serta rasa was-was karena jarak yang begitu jauh, sehingga jika mereka tidak saling menjaga kepercayaan masing-masing, maka akan berdampak pada timbulnya perceraian.

Peran pencari nafkah tidak hanya suami yang berperan, tetapi peran istri sebagai pencari nafkah juga diper hitungkan. Untuk mencari tambahan nafkah bagi keluarga, para istri harus mencari pekerjaan. Sedangkan jumlah tenaga kerja selalu bertambah seiring dengan laju pertumbuhan penduduk yang semakin meningkat disetiap tahunnya, namun hal ini tidak diikuti dengan penyerapan tenaga kerja yang memadai. Rendahnya penyerapan tenaga kerja di dalam Negeri dan kurangnya keterampilan terutama bagi wanita, telah mendorong para pekerja wanita untuk mencari dan memanfaatkan kerja di luar Negeri sebagai TKW.

Perempuan pada umumnya telah mengetahui betapa besarnya resiko bekerja di negara orang, resiko yang paling awal yaitu harus meninggalkan keluarga, Para perempuan yang pergi mencari nafkah ke luar Negeri berharap dapat hidup lebih baik tetapi kenyataan berkata lain. Banyak sekali masalah-masalah yang dihadapi mereka baik dari suami mereka yang menikah lagi maupun kekerasankekerasan yang sering mereka hadapi di perantauan. 
Melihat kondisi sosial desa KalianyarKrangkeng yang minat warganya, terutama remaja wanita dan para istri yang mau bekerja di luar Negeri menjadi TKW ini cukup menggugah penulis untuk melakukan pemberdayaan, guna meminimalisir dampak negative yang ditimbulkan serta memberikan trobosan baru agar masyarakat Desa Kalianyar Krangkeng lebih produktif, sehingga masyarakat mampu membuka lapangan pekerjaan sendiri, agar tidak lagi harus ke luar Negeri sebagai TKW.

Setelah melalukan pendampingan dengan berbagai strategi, dengan meng umpulkan asset-aset yang dimiliki masyarakat desa Kalianyar-Krangkeng ini, seperti banyaknya santri hafal al-Qur'an, pemuda yang berkompeten, masyarakat yang kreatif, dan lain sebagainya, serta dengan keterlibatan stakeholder di Desa Kalianyar-Krangkeng, pendampingan ini menghasilkan beberapa poin, diantara yaitu:

1. Antusias masyarakat dalam kesadaran akan pentingnya pendidikan mulai meningkat, yang diwujudkan pada banyaknya orang tua yang mewajibkan anak-anaknya untuk mengikuti kegiatan belajar mengajar (ngaji ba'da maghrib) di musholah-musholah yang telah tersedia guru ngaji.

2. Pemberdayaan pada alumni santri yang belum mempunyai penghasilan atau pekerjan, dengan bantuan stakeholder tentunya, para alumni diminta untuk mengajar di madrasah-madrasah, sehingga mereka bisa mengamalkan ilmunya serta tidak ada rencana untuk pekerja ke luar Negeri menjadi TKW.

3. Kesadaran masyarakat untuk memulai usaha sendiri, kini sudah terlihat, dengan banyaknya masyarakat yang memulai usaha-usaha kecil, seperti menjual sosis bakar, seblak, gorengan dan lain sebagainya.

4. Organisasi-organisasi masyarakat kini mulai aktif kembali serta sinergi dengan upaya pemberdayaan masyarakat desa Kalianyar-Krangkeng, terutama keluarga TKW, dengan adanya kegiatan rutinitas, baik itu pelatihan-pelatihan, maupun pengajian-pengajian, yang bersifat umum.

5. Meningkatnya kesadaran suami sebagai tulang punggung keluarga, dalam hal ini terwud pada beberapa suami yang melarang istrinya maupun anak perempuannya untuk berangkat ke luar Negeri, sebagai TKW.

Disamping perubahan-perubahan positif yang terjadi, masih ada pula hal-hal negative yang belum terdampingi dengan baik, seperti masih banyaknya kenakalan remaja, karena mereka masih mempertahankan status sosialnya. Namun seiring dengan berjalannya waktu, penulis berharap status sosial tersebut akan bisa membaur dan menyatu serta pro terhadap perubahan positif yang ada di Desa Kalianyar kecamatan Krangkeng kabupaten Indramayu.

\section{E. PENUTUP}

\section{Kesimpulan}

Melihat kondisi sosial desa Kalianyar-Krangkeng yang minat warganya cukup tinggi, terutama remaja wanita dan para istri yang mau bekerja di luar Negeri sebagai TKW, serta banyakya aset masyarakat yang belum digunakan secara maksimal, cukup menggugah penulis untuk melakukan pendampingan/ pemberdayaan. Dalam pendampingan kali ini, penulis menggunakan metode pendampingan Asset Bassed Community Development (ABCD), 
yang tentunya melibatkan beberapa stakeholder seperti perangkat desa Kalianyar, organisasi masyarakat atau perkumpulan warga, tokoh masyarakat dan kepala pembinaan atau penampungan pemberang katan TKW di Desa Kalianyar-KrangkengIndramayu, serta pihak-pihak yang terlibat lainnya. Karena pendampingan ini menggunakan metode $\mathrm{ABCD}$, maka dalam strategi pemecahan masalahnya, penulis menggunakan Model atau Siklus 4-D, yang diwujudkan dengan mengevaluasi kembali organisasiorganisasi masyarakat, dengan mengadakan kegiatan-kegiatan yang positif bagi masyarakat. Dari pendampingan ini menghasilkan perubahan-perubahan positif yang terjadi, meskipun masih ada pula halhal negative yang belum terdampingi dengan baik.

\section{Rekomendasi}

\section{a. Bagi Masyarakat Desa Kalianyar}

Dengan tercapainya beberapa hal positif di masyarakat Kalianyar, diharapkan energi-energi positif yang telah terbentuk, dapat merangkul semua masyarakat di Desa Kalianyar-Krangkeng tersebut. Agar tercapailah keinginan maupun cita-cita masyarakat desa Kalianyar guna menjadi masyarakat yang produktif, yang tidak hanya mengandalkan pekerjaan sebagai TKW.

Bagi masyarakat desa Kalianyar, diharapkan untuk menjaga hal-hal positif yang telah terwujud dalam upaya pemberdayaan, sehingga hal-hal yang telah berubah ke arah yang lebih baik, dapat mendorong masyarakat menuju masyarakat yang pro terhadap perubahan positif, yang pada akhirnya akan tercapailah upaya pemberdayaan tersebut.

\section{b. Bagi Pemerintah}

Dengan melonjaknya jumlah penduduk, maka diharapkan pemerintah memperbanyak lapangan pekerjaan bagi masyarakat, sehingga dapat meminimalisir minat dan keberangkatan masyarakat Indonesia ke luar Negeri sebagai TKW, terutama di kabupaten Indramayu yang merupakan TKW terbesar, serta tingkat perceraiannyapun tertinggi.

\section{c. Bagi Perangkat Desa}

Diharapkan agar tidak hentihentinya memberikan sosialisasi serta pelatihan-pelatihan terhadap kepala keluarga, dalam hal ini para suami, sehingga timbul kesadaran serta kreatifitas pada diri masyarakat tersebut, selain untuk meminimalisir angka perceraian, juga untuk meminimalisir keberangkatan warga ke luar Negeri sebagai TKW. 


\section{DAFTAR PUSTAKA}

Afandi, Agus. (eds). 2014. Modul Participatory Action Research, Surabaya: LPPM UIN Sunan Ampel.

Al-Barry, M Dahlan dan A Partanto Pius. (eds). 2011. Kamus Ilmiah Populer, Surabaya: Bungin.

Daulay, Harmona. 2001. Pergeseran Pola

Relasi Gender di Kelaurga Migran, Yogyakarta : Galang Press.

Dureuau, Christopher. 2013. Pembaru dan Kekuatan Lokal Untuk Pembangunan, Australian Community Development and Civil Society Strengthening Scheme (ACCESS) Tahap II, Agustus.

Fakih, Mansour. 2011. Analisis Gender \& Transformasi Sosial. Yogyakarta: Pustaka Pelajar.

Format Laporan Perkembangan Desa Dan Kelurahan Desa Kalianyar, Kecamatan Krangkeng, Kabupaten Indramayu, 2015.
Goode, Wiilam J. 2004. Sosiologi keluarga, Jakarta: Bumi aksara.

Maya, Ummi. 2012. Kekuatan Doa Ibu, Jakarta: Belanoor, Belabook Media Group.

Munggoro, Dani Wahyu dan Budhita Kasmadi. (eds). 2008. Panduan Fasilitator, Indonesia Australia Part nership: IDSS Acces Phase II.

Narwoko, Dwi dan bagong Sunyoto. (eds), 2006. Sosiologi Teks dan Pengantar Terapan, Jakarta: Kencana.

Tim Penyusun KKN ABCD UIN Sunan Ampel Surabaya. 2015. Panduan KKN ABCD UIN Sunan Ampel Surabaya, Surabaya: LPPM UIN Sunan Ampel.

Undang-Undang Nomor 1 Tahun 1974 tentang Perkawinan, Pasal 45, ayat (1). 